\title{
THE IMPACT OF HISTORICAL AGRICULTURAL LANDUSE ON SELECTED SITE CONDITIONS IN THE TRADITIONAL LANDSCAPE OF THE WEST CARPATHIANS
}

\author{
PAVOL KENDERESSY, JOZEF KOLLÁR, ANDREJ PALAJ
}

Institute of Landscape Ecology, Slovak Academy of Sciences, Štefánikova 3, P.O.Box 254, 81499 Bratislava, Slovak Republic; e-mail: pavol.kenderessy@savba.sk,j.kollar@savba.sk, andrej.palaj@savba.sk

Abstract

Kenderessy P., Kollár J., Palaj A.: The impact of historical agricultural landuse on selected site conditions in the traditional landscape of the West Carpathians. Ekológia (Bratislava), Vol. 39, No. 4, p. 343-356, 2020.

This article is focused on the site conditions of the cultural mountainous West Carpathian landscape (Liptovská Teplička village, Central Slovakia) affected by historical agricultural land use, which also included relief and soil modifications leading to the formation of specific mosaic of agrarian landforms - AL (narrow productive plots separated by balks having character of terraces and mounds). It is based on a pair comparison of sites located side by side; the former is located on the productive plot (former arable land), while the latter is a balk. The pairs were selected in order to capture the representative sample of AL within diverse natural conditions, land cover and management. In order to assess the differences between individual AL, continuous soil water content (SWC) measurements using EC-5 soil moisture sensors were performed. The sensors provided continuous measurements of hourly soil volumetric water content rates $\left(\mathrm{VWC}, \mathrm{m}^{3} / \mathrm{m}^{3}\right.$ ). The data were recorded from April 2018 until December 2018. These data were used to assess individual monitoring localities in terms of SWC temporal stability. Furthermore, at each sampling location, an analysis of soil organic matter content, soil texture and stone content was performed. This research was also supplemented by indirect estimation of some site conditions based on phytoindication method using Ellenberg's indicator values for moisture, soil reaction, nutrient content, continentality, temperature and light. Our results can be concluded as follows: i) the SWC temporal stability assessment revealed the clear effect of $\mathrm{AL}$, however, it was difficult to identify which factors associated with AL typology were the most significant. The high differences between similar AL types revealed the fact that land use, management and rock content (both at productive plots and balks) affect the SWC temporal stability rather than AL typology and their orientation within the slope, ii) phytoindication method did not show statistically significant differences in site conditions between productive plots and balks, despite the fact that there were some significant differences confirmed in species composition, especially between productive plots and dolomite mounds. These differences are related to a higher number of calciphilous and termophilous species preferring ecotones and forests in mounds and group of mesophilous meadow species in productive plots. In summary, it seems that identified differences in both SWC temporal stability and floristic composition between productive plots and balks reflect the management regime rather than site conditions and formation of mounds represents relatively the most significant impact of traditional agricultural land use on the local environment.

Key words: traditional management, changes, site conditions, Carpathians. 


\section{Introduction}

The structure of the landscape has long been influenced by agricultural use. A special example of a mountain landscape, the appearance of which is significantly affected by traditional management, is the study area of Liptovská Teplička village located in a remote part of the Western Carpathians. It is characterised by well-preserved mosaic of narrow fields separated by balks, which include various terraces, mounds and their combinations (Špulerová et al., 2011a; Dobrovodská, 2014), makes this region unique, since most of such territories perished in the post-socialist countries under the pressure of socialist agriculture, which preferred intensive management in large-scale fields created by merging of small plots (Bezák, Mitchley, 2014; Lieskovský et al., 2014). The primary function of agrarian landforms was to support intensive agriculture in steep hillslopes and to gain farming production in the long term (Arnáez et al., 2015). Farming terraces help to protect the soil by increasing infiltration rates and decreasing runoff and sediment production. Under optimum conditions, they form a hydraulic equilibrium state between the geomorphic settings and the anthropogenic use (Schönbrodt-Stitt et al., 2013). On steep slopes, they reduce the slope inclination and slope length, which results in modification of hydrological connectivity and overland flow (Nyssen et al., 2009; Zhang et al., 2014). Several authors described the effect of overland flow and flow velocity reduction, which promotes the water infiltration in relatively flat areas created between terraces (Van Wesemael et al., 1998; Lu et al., 2009; Xu et al., 2017). Agrarian stone mounds (built by stones collected from cultivated fields) are considered to be porous linear drainage elements. Štibinger (2011) performed an infiltration experiment, where he compared the infiltration capacity and hydro-physical characteristics of stone mounds and surrounding fields. The results showed a significant difference in infiltration capacity between stone mounds and fields between themthe porous environment of stone mounds exhibited similar hydro-physical properties as small gravel. The studies mentioned above confirm the fact that agrarian landforms, such as terraces and mounds, could be considered not only as barriers of surface flow, but also as elements with drainage and infiltration capabilities, that could capture the potential runoff and act as linear infiltration elements, which significantly affect the hydrological properties of surrounding landscape (Kovár et al., 2011). However, comprehensive scientific information concerning their effect on soil moisture regime and water retention have not been available so far. Therefore, the study area offers a great opportunity to study the impact of historical land use with its relief and soil modifications on soil moisture regime. Soil moisture is a key state variable for understanding a large number of hydrological processes involved in a broad variety of natural processes (geomorphological, climatic, ecological) that act at different spatio-temporal scales (Entin et al., 2000). Soil moisture is also one of the main factors affecting infiltration/runoff dynamics. It is well known that SWC has a complex relation with time and/or space because of the heterogeneity of rainfall patterns, land use and management, landscape and soil hydrological properties (Heathman et al., 2012). In addition, spatial and temporal patterns of SWC are influenced by other elements, like those related to local topography (Korres et al., 2015). Many studies have identified important relationships between spatial and temporal SWC variability and the geomorphological heterogeneity of the space (Choi, Jacobs, 2007), the observational scale (Gao, Shao, 2012) and external elements, like the climate (Zhao et al., 2010). 
In this article, we compare some site conditions between managed parcels and adjacent unmanaged balks of various characters. The main goal is to compare the temporal water content stability based on soil moisture data collected during the period of one year. In addition, those results are supplemented by indirect estimation of site conditions such as moisture, soil reaction, nutrient contents, continentality, temperature and light using phytoindication method, which is based on Ellenberg's indicator values.

\section{Material and methods}

\section{Study area}

The study area includes the cadastre of Liptovská Teplička village (Fig. 1). It is a traditional farming mountain region (altitude between 846-1429 m a.s.l.) located in the eastern part of the Low Tatras Mts., which is a part of the West Carpathians in Slovakia. The study area falls within a cold climatic region with average temperature between 12 and $16^{\circ} \mathrm{C}$ in July and between -6 and $-7{ }^{\circ} \mathrm{C}$ in January. According to the latest measurement taken in 2018 by an automatic meteorological station located in the study area, the lowest temperature of $-20.1^{\circ} \mathrm{C}$ was recorded in January, the highest temperature of $28.3^{\circ} \mathrm{C}$ was recorded in June. The annual precipitation rate was $861 \mathrm{~mm}$ with highest rainfall precipitation recorded on July 17, 2018, with a total rainfall amount of $51 \mathrm{~mm}$ and duration of 18 hours
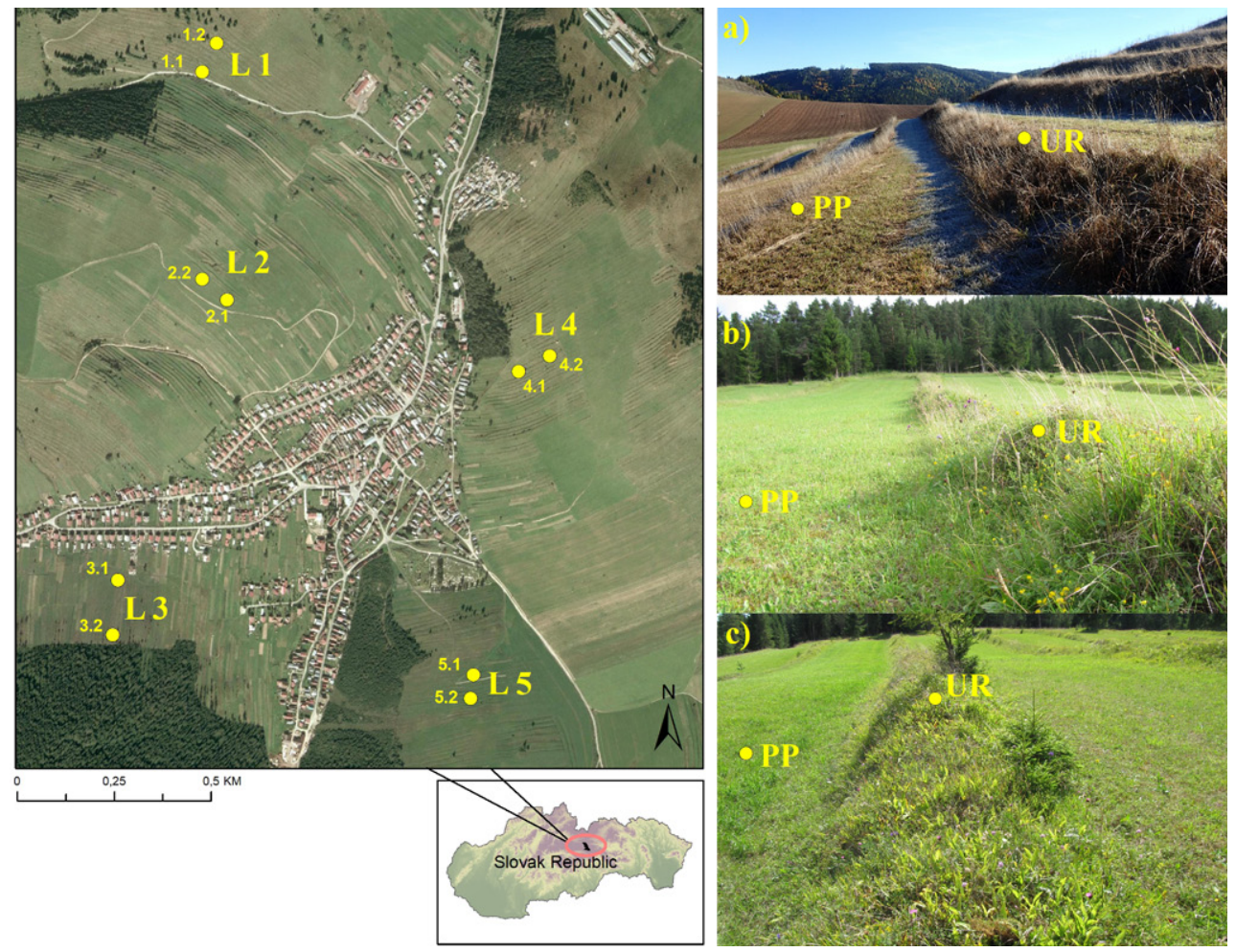

Fig. 1. Localization of the study area of Liptovská Teplička village and typology of agrarian landforms (AL): a) terrace b) mound c) mound-terrace. 
(Fig. 2). The natural soils are mostly shallow and skeletal Rendzic Leptosols and Cambisols (Balkovič et al., 2014). In addition, anthropic relief forms (balks made of gathered stones) are covered by Anthropic Regosols. Potential vegetation includes predominantly fir and fir-spruce forests, and to a lesser extent also acidophilous beech forests (Michalko et al., 1986), while real vegetation is mainly represented by various grasslands (Ružičková et al., 1999) and spruce monocultures.

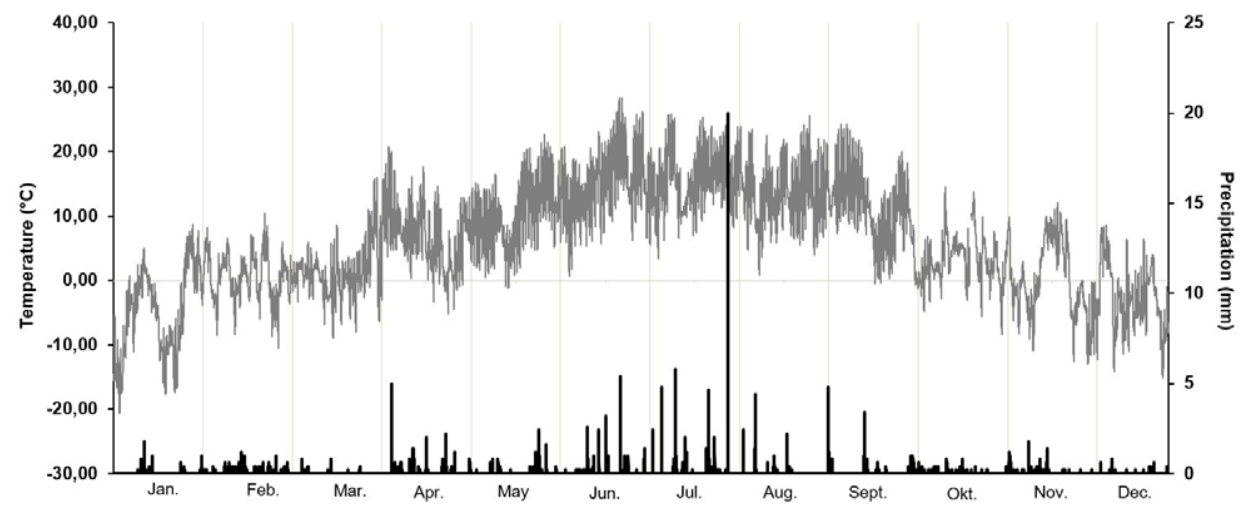

Fig. 2. Precipitation and temperature records for the study area of Liptovská Teplička, year 2018.

The area was colonized in the early 17 th century. The standard of living of the locals was low in the harsh mountain conditions and they made their living from forestry and farming. Due to specific ownership rights related to land acquisition and purchase, based on the Tripartium Law of 1517, which was practically in force until 1947, the whole agrarian area of Liptovská Teplička was gradually divided into a number of long and narrow parcels with field margins and traditional agrarian landforms (AL) such as: (1) terraces, (2) mounds and (3) mound-terraces (Fig. 1). During agricultural intensification after 1975, many of the agrarian landforms were removed and the land was transformed into large-scale intensively used grasslands and arable fields. However, due to the extreme conditions mostly not suitable for conventional farming, specific mosaics of pastures, meadows, small arable plots and agrarian landforms have been preserved until present time. In 2009, the total area of agricultural land was 1313 ha, out of which 386 ha was characterised as traditional agrarian landscape. The land area with the presence of AL covers 293 ha, out of which $65 \%$ are terraces and $35 \%$ are represented by mounds (Špulerová et al., 2011b).

\section{Characterization of agrarian landforms}

According to Ružičková et al. (1999) and our field research, AL in Liptovská Teplička include three basic genetic groups (Fig. 1):

1. Terraces, which have been formed to get a flat surface suitable for cultivation. These consist of relatively flat, narrow, only a few meters wide arable plots, which are separated by steep, almost perpendicular balks covered by unmanaged grasslands with soils with medium up to high rock content.

2. Mounds, which have been created by long-term collection of rocks from arable land and their accumulation on parcel boundaries. The share of rocks and soil material in the mounds varies, however, in general, they contain more rock material than terraces.

3. Mound-terraces, which have been created by a combination of measures mentioned above.

\section{Soil water content data collection}

In order to capture the representative sample of $\mathrm{AL}$ within diverse natural conditions, land cover and management, 5 monitoring localities (L) were selected. At each locality, one footslope (1) and one upslope (2) position was selected. 


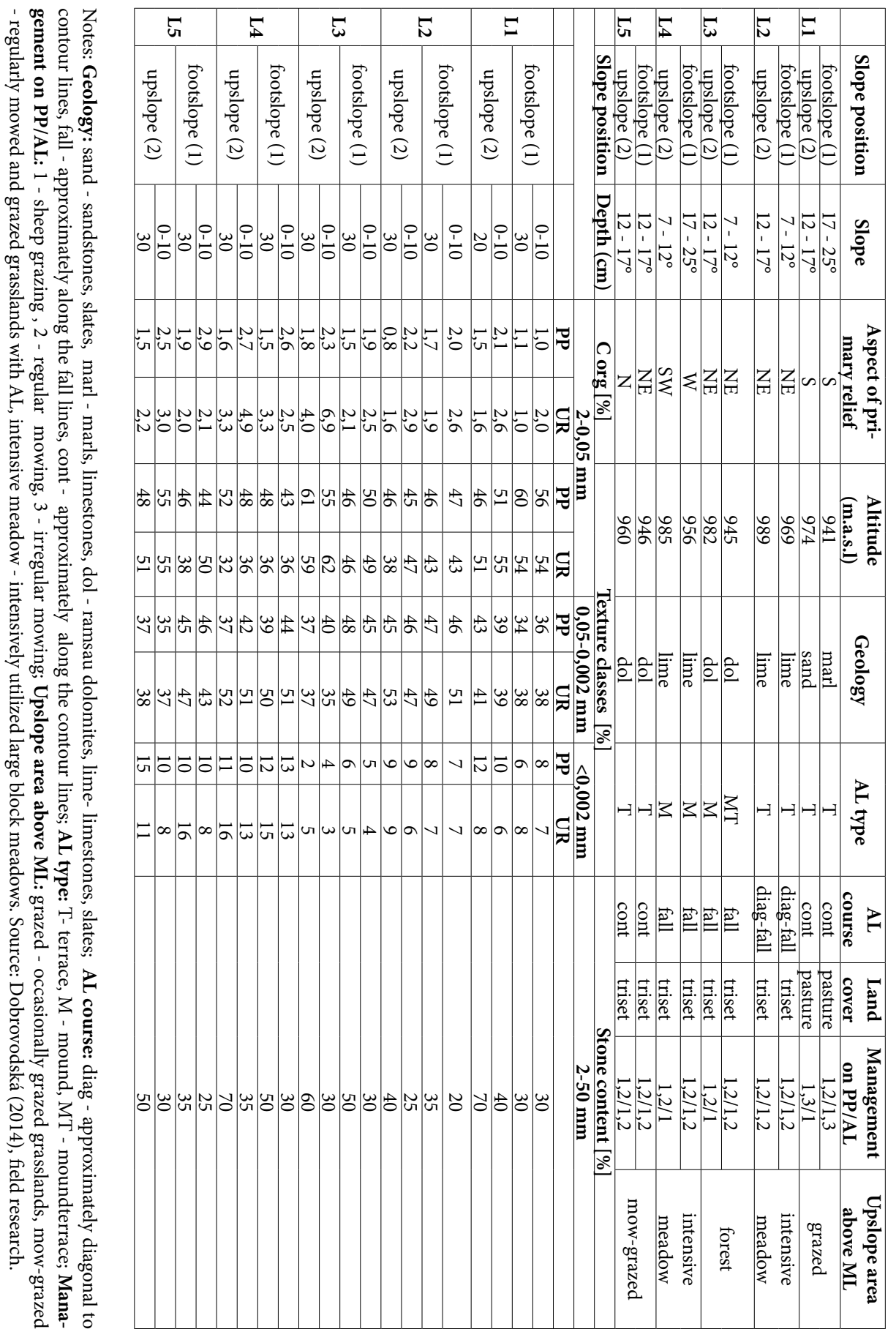

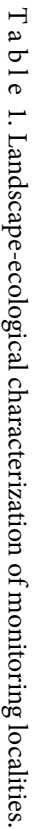


Furthermore, at each slope position, two monitoring sites were selected-the upper rim of the balk (UR), and the productive plot (PP) (Fig. 1). Continuous soil water content (SWC) measurements were performed using EC-5 soil moisture sensors determining the volumetric water content (VWC, $\mathrm{m}^{3} / \mathrm{m}^{3}$ ) attached to EM5b Analog Data Loggers (Decagon devices, Inc.). The sensors provide continuous measurements of hourly soil moisture rates. The sensors were installed at two depths, $10 \mathrm{~cm}$ and $30 \mathrm{~cm}$. Due to very high skeleton content, the root zone depth of $30 \mathrm{~cm}$ was a maximum depth, where sensors could be safely installed. In total, there were 40 sampling sites selected. The data were recorded from April 2018 until December 2018. Furthermore, at each sampling site, an analysis of soil organic matter content, soil texture and stone content was performed (Table 1).

\section{Temporal soil water content stability assessment}

The most common method for analysing temporal stability of SWC is based on the relative difference (RD). This statistical indicator is defined as the difference between SWC individually observed in time $\mathrm{j}$ and location $\mathrm{i}$ (SWCij) and the average of these values in time $\mathrm{j}$. The analysis of RD can be used to estimate the positive or negative bias of SWC during each field survey. The RD was calculated as follows (Liu, Shao, 2014; Vachaud et al., 1985):

$$
R D_{i j}=\frac{S W C i j-\overline{S W C} j}{\overline{S W C} j},
$$

where RDij is the deviation of SWC at location i from the mean SWC at the sampling time j, SWCij is the SWC at location $i$ and the sampling time $j$, and $\overline{\mathrm{SWC}} \mathrm{j}$ is the mean SWC of measured at all sampling sites during the sampling time $\mathrm{j}$. The mean SWC was computed as follows:

$$
\overline{\mathrm{SWC}} \mathrm{j}=\frac{1}{\mathrm{n}} \sum_{\mathrm{i}=1}^{\mathrm{n}} \mathrm{SWC}_{\mathrm{ij}},
$$

where $\mathrm{n}$ is the total number of sampling sites at the sampling time $\mathrm{j}$. In this study, $\mathrm{n}$ was equal to 40 .

The mean relative difference (MRD) and its standard deviation of relative difference (SDRD) at sampling site $i$ and sampling time $\mathrm{j}$ were calculated as:

$$
\begin{aligned}
\operatorname{MRD}_{i} & =\frac{1}{m} \sum_{j=1}^{m} R_{i j} \\
\operatorname{SDRD}_{i} & =\sqrt{\frac{1}{m-1} \sum_{j=1}^{m}\left(R D_{i j}-M_{i} D_{i}\right)^{2}},
\end{aligned}
$$

where $\mathrm{m}$ is the total number of sampling times. The mean relative difference (MRD) values were calculated and were plotted against their rank, along with their corresponding temporal standard deviations (SDRD). The lower the difference (positive or negative) between SWCij and SWCj, the closer MRD is to zero value, the lower SDRD is. Low values of SDRD correspond to high temporal stability, whereas high values of SDRD are associated with low temporal variability (Ben-Salem et al., 2018; López-Vicente, Álvarez, 2018). In our case, the positive MRD values indicate higher SWC capacity, while negative MRD values indicate lower SWC capacity. The MRD and SDRD values were calculated using hourly SWC records for each of the 40 sampling locations for the whole monitoring period from April 2018 until December 2018 (5831 records in total). Furthermore, for each of the monitoring sites, positions on agrarian landform (PP, UR), slope position (footslope, upslope) and soil depth $(10,30 \mathrm{~cm})$, the basic statistical variables such as average MRD, minimum and maximum MRD value and range (the difference between min. and max. MRD value) were also calculated.

\section{Vegetation data collection and analyses}

The methods of Zürich-Montpellier School of phytosociology (Braun-Blanquet, 1964) were used to sample vegetation at all sites equipped with a datalogger, that is, 10 pairs of phytocoenological relevés were sampled on June 8 and 9, 2020. The 7-figure Braun-Blanquet scale was used to estimate the species coverage. Phytocoenological relevés are stored in the Central Database of Phytocoenological Relevés (Hegedüšová 2007). Vascular plant nomenclature was modified according to Marhold, Hindák (1998). Cryptograms are not included. Ellenberg's indicator values (Ellenberg et al., 1992) (EIV) were deployed to estimate site conditions (moisture, light, temperature, soil reaction, nutri- 
ent content, continentality) and only species presence/absence data were used. For the storage of vegetation data, we used the Turboveg program (Hennekens, Schaminée, 2001). For its editing and post-processing, we employed the Juice program (Tichý, 2002) used also to compute Ellenberg's indicator values for individual relevés. We performed a paired t-test to compare the differences between site conditions of productive plots and balks. Relevé (dis)similarity was estimated as a shift of a point in the multidimensional space. Ordination was made as non-metrical multidimensional scaling (nMDS), while each relevé in the plot represents a point in the ordination space. Finally, we used the envfit function to fit EIV onto an ordination (Oksanen et al., 2019). Differences in the structure of phytocoenoses were also tested by paired t-test using species presence/absence data.

\section{Results}

SWC temporal stability differences between monitoring localities, positions on agrarian landform, slope position and soil depths

The results of SWC temporal stability assessment are presented at Figure 3, where MRD values are ranked from the smallest to largest for each locality (Fig. 3a), positions on agrarian landform (Fig. 3b), slope position (Fig. 3c) and soil depth (Fig. 3d). The basic statistical variables (average MRD, minimum and maximum MRD value and range) were summed up in Table 2. In general, the results show that some sampling sites systematically either overestimate $(\mathrm{MRD}>0)$ or underestimate $(\mathrm{MRD}<0)$ the field average SWC regardless of the observation time. For instance, the water storage in sampling site L3_2_UR_30 is 50\% ( $\pm 7 \%)$ smaller than the field average, whereas that in location L2_2_PP_10 is higher by $50 \%( \pm 18 \%)$. We could observe that locality L1 exhibits significantly different pattern than other localities. In case of L1, all values are lower than 0 , which indicates low SWC capacity (average MRD = -15.7). However, the low difference $(17.8 \%)$ between minimum $(-5.8 \%)$ and maximum $(-23.7 \%)$ MRD values indicates relatively high similarity between individual sampling locations in terms of SWC content. Locality L2 is characterised by MRD values ranging from -19.5 to $50 \%$, which is the highest maximum value among all localities with relatively high difference (69\%). The average MRD value (6.4\%) indicates higher SWC capacity. Locality L3 is characterised by MRD values ranging from $-50 \%$, which represents lowest minimum MRD value among all localities, to maximum value of $11.7 \%$ with a difference of $61.9 \%$. The average MRD value (-12.1\%) indicates lower water storage potential. Locality L4 is characterised by a difference of $67.2 \%$ between minimum (-30.9\%) and maximum $(36.2 \%)$ MRD values. The average MRD value (6.4\%) indicates higher SWC capacity. Locality L5 is characterised by the highest average MRD value (13\%), which makes it a locality with the highest SWC capacity. The MRD values range from -26.8 to $42.6 \%$ with the range of $69.4 \%$.

\section{Differences in floristic composition between productive plots and balks}

All the sites are covered by grasslands. Since the forests are the climax vegetation in the area, these grasslands represent various successional stages determined by land use and management (mowing, mulching, grazing). Generally, vegetation is mainly made of mesophilous meadow species, which are accompanied by those typical for xero-thermophilus grasslands. Depending on particular conditions, also species preferring acidophilous grasslands, ecotones and forests occur to various extents (Table 3). In general, vegetation of productive plots 

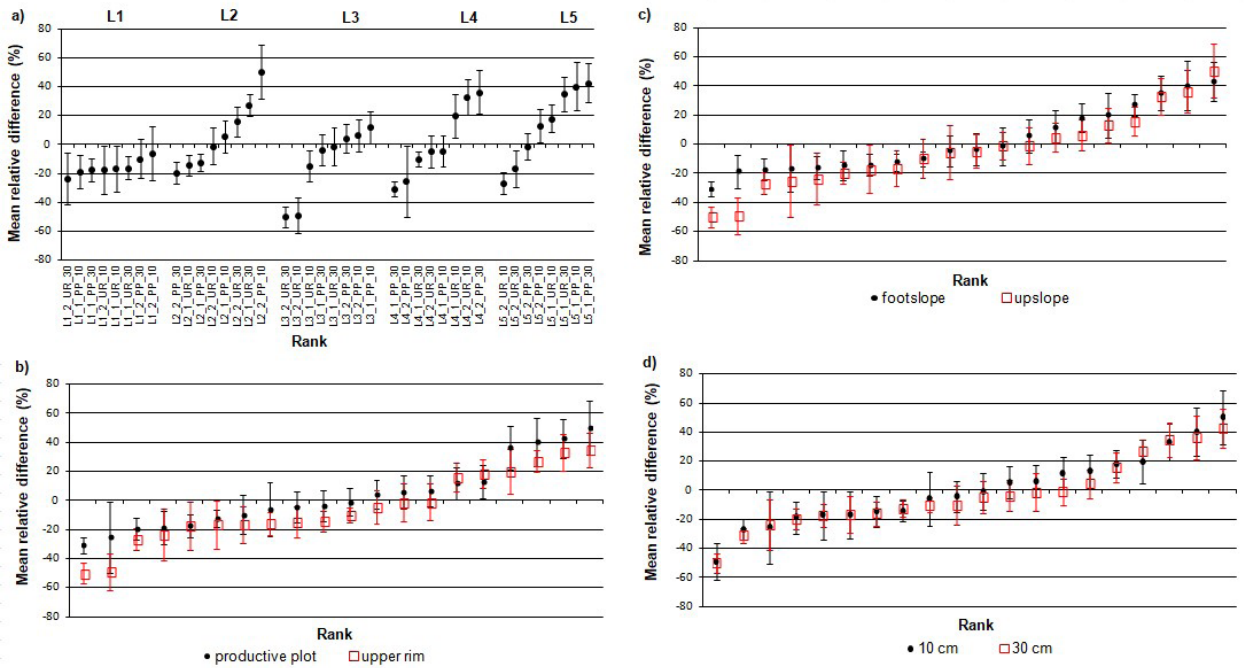

Fig. 3. Comparison of mean relative differences (MRD) in soil water contents over a year between different localities (a), positions on agrarian landform (b), slope position (c) and soil depth (d). Vertical bars represent \pm standard deviation values (SDRD).

T a b l e 2. Basic statistical variables describing the variability of MRD values between different localities, positions on agrarian landform, slope position and soil depth.

\begin{tabular}{|c|c|c|c|c|}
\hline & \multicolumn{4}{|c|}{ MRD (\%) } \\
\hline & Average & Min. & Max. & Range \\
\hline \multicolumn{5}{|l|}{ monitoring locality } \\
\hline L1 & $-15,7$ & $-23,7$ & $-5,9$ & 17,9 \\
\hline L2 & 6,4 & $-19,5$ & 50,3 & 69,8 \\
\hline L3 & $-12,0$ & $-50,1$ & 11,8 & 61,9 \\
\hline L4 & 1,7 & $-30,9$ & 36,3 & 67,2 \\
\hline L5 & 13,0 & $-26,8$ & 42,6 & 69,5 \\
\hline \multicolumn{5}{|l|}{ position on slope } \\
\hline footslope (1) & 2,0 & $-30,9$ & 42,6 & 73,6 \\
\hline upslope (2) & $-4,6$ & $-50,1$ & 50,3 & 100,4 \\
\hline \multicolumn{5}{|l|}{ soil depth } \\
\hline $10 \mathrm{~cm}$ & 0,2 & $-49,0$ & 50,3 & 99,3 \\
\hline $30 \mathrm{~cm}$ & $-2,8$ & $-50,1$ & 42,6 & 92,7 \\
\hline \multicolumn{5}{|l|}{ position at $\mathrm{AL}$} \\
\hline productive plot (PP) & 3,0 & $-30,9$ & 50,3 & 81,2 \\
\hline upper rim (UR) & $-5,7$ & $-50,1$ & 34,8 & 84,9 \\
\hline
\end{tabular}

and balks is not identical. As shown by nMDS (Fig. 4), vegetation of managed productive plots is more homogenous than that of balks. It is mainly composed of mesophilous meadow species depending on more or less regular management. On the other hand, relatively het- 
erogeneous balk vegetation corresponds with a greater diversity of site conditions (various relief, skeleton content, light regime, etc.). In addition, balks are managed only extensively and irregularly. Therefore, besides typical grassland species, also those typical for ecotones and light-demanding forests as well as some phanerophytes occur here. This is especially noticeable in the mounds made of dolomite rocks as indicated by Aquilegia vulgaris, Astrantia major, Calamagrostis varia, Convallaria majalis, Rubus saxatilis, Scabiosa lucida and some others. It is confirmed by pair t-test (Table 3), which identified significant differences between floristic composition of balks and adjacent productive plots mainly in sites L3_1, L3_2. It is caused mostly by the number of species, which is higher in balks than in adjacent productive plots by about $40 \%$. Significant difference was found also for the L5_1 site, which includes terraces. However, contrary to the L3 sites, it is poorer in the number of species by more than $30 \%$ in balk, since unmanaged dense vegetation hand in hand with a steep relief does not provide proper conditions for low-growing and less competitive species.

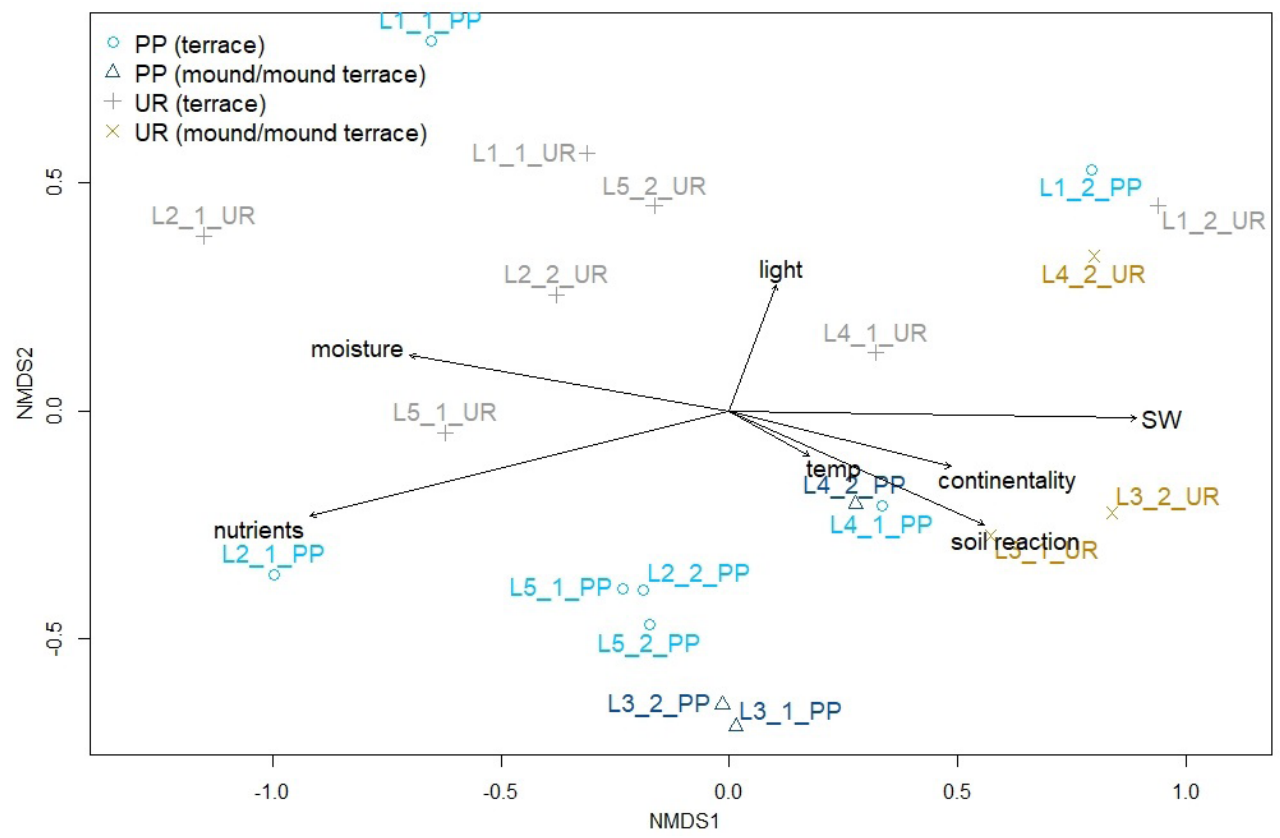

Fig. 4. NMDS ordination diagram showing the distribution of production plot and balks relevés.

Phytoindicated differences in site conditions between productive plots and balks

Light is estimated as the most important factor that distinct the productive plots from balks in individual pairs (Table 4). However, despite some confirmed differences in floristic composition, none of the ecological factors was confirmed as statistically significant. Relatively, the biggest differences were revealed for the L3 sites. Here, dolomite rocky mounds are drier 
$\mathrm{T} \mathrm{a} \mathrm{b} \mathrm{l} \mathrm{e} \mathrm{3.} \mathrm{Results} \mathrm{of} \mathrm{the} \mathrm{paired} \mathrm{t-test} \mathrm{comparing} \mathrm{the} \mathrm{species} \mathrm{composition} \mathrm{of} \mathrm{the} \mathrm{production} \mathrm{plots} \mathrm{and} \mathrm{balks} \mathrm{(upper}$ rim) (significance level: $\alpha=0.05^{*}$ ).

\begin{tabular}{|c|c|c|}
\hline sampling site & t-value & p-value \\
\hline L1_1 & $-0,39113$ & 0,6963 \\
\hline L1_2 & $-0,59872$ & 0,5503 \\
\hline L2_1 & 1,4045 & 0,1622 \\
\hline L2_2 & 1,1219 & 0,2637 \\
\hline L3_1 & $-2,3958$ & $0,01782^{*}$ \\
\hline L3_2 & $-1,9995$ & $0,04736^{*}$ \\
\hline L4_1 & 0,19184 & 0,8481 \\
\hline L4_2 & $-1,1219$ & 0,2637 \\
\hline L5_1 & 2,2192 & $0,02798^{*}$ \\
\hline L5_2 & 1,152 & 0,2511 \\
\hline
\end{tabular}

Notes: 1 - footslope position; 2 - upslope position.

$\mathrm{T}$ a b le 4. Comparison of values for production plots and balks (upper rim) site conditions estimated by Ellenberg's eco-indices and results of the paired t-test (significance level: $\alpha=0.05^{\star}$ ).

\begin{tabular}{|c|c|c|c|c|c|c|c|}
\hline sampling site & NoS & Light & Temp & Cont & Moisture & Nutrients & pH \\
L1_1_PP & 25 & 6,93 & 5,25 & 3,38 & 4,91 & 5 & 6,56 \\
L1_1_UR & 27 & 7,18 & 5,25 & 3,79 & 4,29 & 4,4 & 6,9 \\
L1_2_PP & 46 & 7,44 & 5,31 & 4,04 & 4,14 & 3,64 & 6,52 \\
L1_2_UR & 49 & 7,26 & 5,23 & 3,86 & 3,83 & 3,55 & 6,62 \\
L2_1_PP & 32 & 7,05 & 4,83 & 3,63 & 5 & 5,19 & 6,55 \\
L2_1_UR & 25 & 7,08 & 5,33 & 4,09 & 4,92 & 4,64 & 6,63 \\
L2_2_PP & 45 & 7,27 & 5,54 & 4 & 4,48 & 4,56 & 6,79 \\
L2_2_UR & 37 & 7,05 & 5 & 3,79 & 4,61 & 4,61 & 6,43 \\
L3_1_PP & 40 & 7,17 & 5,57 & 3,95 & 4,48 & 4,06 & 6,44 \\
L3_1_UR & 56 & 7,03 & 5,13 & 4,06 & 4,09 & 3,79 & 7,58 \\
L3_2_PP & 34 & 7,18 & 5,43 & 4,23 & 4,5 & 4,54 & 6,91 \\
L3_2_UR & 48 & 6,93 & 5,33 & 4,43 & 3,97 & 3,34 & 7,63 \\
L4_1_PP & 44 & 7,19 & 5,73 & 4,08 & 4,04 & 4,09 & 7,5 \\
L4_1_UR & 43 & 7,29 & 5,73 & 4,48 & 4 & 3,95 & 7,53 \\
L4_2_PP & 44 & 7,41 & 5,71 & 4,22 & 3,96 & 3,63 & 7,32 \\
L4_2_UR & 51 & 6,94 & 5,39 & 4,28 & 4 & 3,88 & 7,54 \\
L5_1_PP & 39 & 7,26 & 5,45 & 3,83 & 4,36 & 4,42 & 7 \\
L5_1_UR & 27 & 7,07 & 5 & 4,08 & 5 & 5,53 & 6,11 \\
L5_2_PP & 38 & 7,13 & 5,36 & 3,91 & 4,22 & 4,29 & 7,07 \\
L5_2_UR & 31 & 6,82 & 5,5 & 3,76 & 4,41 & 4,53 & 6,83 \\
\hline
\end{tabular}

Notes: 1 - footslope position; 2 - upslope position; UR - upper rim; PP - productive plot. 
and with higher soil $\mathrm{pH}$ as well as nutrient content than corresponding productive plots. As mentioned above, it is caused by a higher number of calciphilous and thermophilus species preferring ecotones and forests in balks and group of mesophilous meadow species in productive plots.

\section{Discussion}

The results revealed the clear effect of agrarian landforms' presence on SWC temporal stability; however, each monitoring locality was characterised by its own regime. Three localities (L1, L2 and L5), which are typologically similar (the presence of terraces oriented along the contour lines) exhibit significantly different values in terms of SWC temporal stability. Locality $\mathrm{L} 1$ is characterized by lowest average MRD value as well as low MRD value range. This is related mainly to vegetation biomass accumulation due to lower management intensity in comparison with other localities. According to Yang et al. (2012) and Sun et al. (2013), the biomass quality and quantity influence on soil moisture is considered important, especially in case of topsoil's moisture variability. Localities L3 and L4 are also typologically similar (mounds and mound-terraces oriented downslope); however, in terms of temporal SWC stability, they also exhibit significantly different values. Locality L3, which is characterized by intensive management (regular mowing twice a year, fertilization) shows significantly lower average MRD value than locality L4. The lower average MRD values at agrarian landforms in comparison with the productive plots indicate their lower SWC capacity. Llorens and Gallart (1992) stated that well maintained terraces in the Mediterranean climate are capable of fully retaining the rainfall of approximately $50 \mathrm{~mm}$ over 24 hours without generating runoff. This process mainly affects the inner parts of the terraces (in our case PP), which become saturated during periods of rain (Gallart et al., 2002). Some other research related to water infiltration on terraces showed that the infiltration capacity of the soil is not particularly affected by terracing; however, the soil stays humid for a longer time in flat part of the terrace than in sloping fields (Posthumus, Stroosnijder, 2010). We have assumed that high rock content at AL would induce greater infiltration rates, thus the overall SWC and its temporal stability would be lower than on productive plots. High rock content could also be associated with lower average MRD at $30 \mathrm{~cm}$ in comparison with $10 \mathrm{~cm}$ and also lower average MRD values at upslope positions in comparison with footslope positions. This could be partially explained by the fact that upslope positions are often characterised by higher stone content and removal of fine soil material, especially due to continued arable cultivation and related runoff processes in the past. Rock fragments in the soil may influence water movement and solute transport by affecting the soil structure and the tortuosity of water flow paths, which may make water movement and solute transport more complex than in a stone-less soil (Ma, Shao, 2008; Zhou et al., 2009). The presence of stones can result in lower hydraulic conductivities (Bouwer, Rice, 1984; Ma et al., 2010; Novák et al., 2011). In contrast, shrink-swell phenomena may create temporal lacunar pores that can cause an increase in the saturated hydraulic conductivity (Verbist et al., 2013; Hlaváčiková et al., 2016). Generally, it can be concluded that differences in floristic composition between productive plots and balks reflect the management regime rather than site conditions. The SWC temporal stability assessment revealed the clear effect of AL, however, it was difficult to identify which factors associated 
to AL typology are most significant in terms of SWC temporal stability. Results of floristic composition between productive plots and balks comply with those reported by Ružičková et al. (1999), who sampled 58 phytocoenological relevés in the area and confirmed that mounds are the best floristically distinguished from among local grasslands by high number of species, which mostly prefer thermophilus forest and ecotones. The high differences between localities characterised by similar typology point to the fact that these differences could be associated rather to different factors (such as land use and management) than to those directly related to AL typology. Specifically, the land use and management could significantly alter the effect of agrarian landforms on SWC variability.

\section{Acknowledgements}

The contribution was prepared within the grant project of the Ministry of Education of the Slovak Republic and the Slovak Academy of Sciences No. 2/0118/18 'Changes in soil properties and secondary succession following afforestation of former agricultural land' and No. 2/0078/18 'Research of biocultural values of landscape'.

\section{References}

Arnáez, J., Renault, N.L., Lasanta, T., Flaño, P.R. \& Castroviejo J. (2015). Effects of farming terraces on hydrological and geomorphological processes. A review. Catena, 128, 122-134. DOI: 10.1016/j.catena.2015.01.021.

Balkovič, J., Bedrna, Z., Čurlík, J., Dlapa, P., Fulajtár, E., Gömöryová, E., Gregor, J., Hanes, J., Houšková, B., Hutár, V., Chlpík, J., Ilavská, B., Juráni, B., Kobza, J., Kotorová, D., Kukla, J., Kuklová, M., Machava, J., Nádašský, J., Nochta, P., Nováková, K., Orfánus, T., Pavlenda, P., Pichler, P., Pišút, P., Skalský, R., Sobocká, J., Polláková, N, Šimanský, V., Tatarková, Z., Tobiášová, E., Zaujec, A. (†) \& Zverková A. (2014). Morfogenetický klasifikačný systém pôd Slovenska. Bazálna referenčná taxonómia. Bratislava: SPS, NPPC VÚPOP.

Ben-Salem, N., Álvarez, S. \& López-Vicente M. (2018). Soil and water conservation in rainfed vineyards with common sainfoin and spontaneous vegetation under different ground conditions. Water, 10(8), 1058. DOI: 10.3390/ w10081058.

Bezák, P. \& Mitchley J. (2014). Drivers of change in mountain farming in Slovakia: from socialist collectivisation to the Common Agricultural Policy. Regional Environmental Change, 14, 1343-1356. DOI: 10.1007/s10113-0130580-x.

Bouwer, H. \& Rice R.C. (1984). Hydraulic properties of stony vadose zones. Ground Water, 22(6), 696-705. DOI: 10.1111/j.1745-6584.1984.tb01438.x.

Braun-Blanquet, J. (1964). Pflanzensoziologie. Grundzüge der Vegetationskunde. Wien, New York: Springer Verlag.

Choi, M. \& Jacobs J.M. (2007). Soil moisture variability of root zone profiles within SMEX02 remote sensing footprints. Advances in Water Resources, 30(4), 883-896. DOI: 10.1016/j.advwatres.2006.07.007.

Dobrovodská, M. (2014). Krajinnoekologický výskum historickej polnohospodárskej krajiny v obciach Liptovská Teplička, Osturňa a Malá Franková. Bratislava: Veda, vydavatelistvo SAV.

Ellenberg, H., Weber, H.E., Dull, R., Wirth, W., Werner, W. \& Paulissen D. (1992). Zeigerwerte von Pflanzen in Mitteleuropa. Scripta Geobotanica, 18, 1-258.

Entin, J.K., Robock, A., Vinnikov, K.Y., Hollinger, S.E., Liu, S. \& Namkhai A. (2000). Temporal and spatial scales of observed soil moisture variations in the extratropics. Journal of Geophysical Research, 105, 11865-11877. DOI: 10.1029/2000JD900051.

Gao, L. \& Shao M.A. (2012). The interpolation accuracy for seven soil properties at various sampling scales on the Loess Plateau, China. Journal Soils Sediments, 12, 128-142. DOI: 10.1007/s11368-011-0438-0.

Gallart, F., Llorens, P., Latron, J. \& Regüés D. (2002). Hydrological processes and their seasonal controls in a small Mediterranean mountain catchment in the Pyrenees. Hydrology and Earth System Sciences, 6(3), 527-537. DOI: 10.5194/hess-6-527-2002.

Heathman, G.C., Cosh, M.H., Merwade, V. \& Han E. (2012). Multi-scale temporal stability analysis of surface and subsurface soil moisture within the Upper Cedar Creek Water-shed, Indiana. Catena, 95, 91-103. DOI: 10.1016/j.catena.2012.03.008. 
Hegedüšová, K. (2007). Central Database of Phytocoenological Relevés in Slovakia (in Slovak with English abstract). Bull. Slov. Bot. Spoločn, 29, 124-129.

Hennekens, S. \& Schaminée J.H.J. (2001). TURBOVEG, a comprehensive data base management system for vegetation data. J. Veg. Sci., 12, 589-591. DOI: 10.2307/3237010.

Hlaváčiková, H., Novák, V. \& Šimůnek J. (2016). The effects of rock fragment shapes and positions on modeled hydraulic conductivities of stony soils. Geoderma, 281, 39-48. DOI: 10.1016/j.geoderma.2016.06.034.

Korres,W., Reichenau, T.G., Fiener, P., Koyama, C.N., Bogena, H.R., Cornelissen, T., Baatz, R., Herbst, M., Diekkruger, B., Vereecken, H. \& Scheider K. (2015). Spatio-temporal soil moisture patterns - a meta-analysis using plot to catchment scale data. J. Hydrol., 520, 326-341. DOI: 10.1016/j.jhydrol.2014.11.042.

Kovář, P., Štibinger, J. \& Kasl M. (2011). Agrární valy a vodní režim. Praha: ČZU.

Lieskovský, J., Kenderessy, P., Špulerová, J., Lieskovský, T., Koleda, T., Kienast, P. \& Gimmi U. (2014). Factors affecting the persistence of traditional agricultural landscapes in Slovakia during the collectivization of agriculture. Lands. Ecol., 29(5), 867-877. DOI: 10.1007/s10980-014-0023-1.

Liu, B. X. \& Shao M.A. (2014). Estimation of soil water storage using temporal stability in four land uses over 10 years on the Loess Plateau, China. J. Hydrol., 517, 974-984. DOI: 10.1016/j.jhydrol.2014.06.003.

López-Vicente, M. \& Álvarez S. (2018). Stability and patterns of topsoil water content in rainfed vineyards, olive groves, and cereal fields under different soil and tillage conditions. Agric. Water Manag., 201, 167-176. DOI: 10.1016/j.agwat.2018.02.004.

Llorens, P. \& Gallart F. (1992). Small basin response in a Mediterranean mountainous abandoned farming area: research design and preliminary results. Catena, 19(3-4), 309-320. DOI: 10.1016/0341-8162(92)90005.

Lu, H., Zhu, Y., Skaggs, T.H. \& Yu Z. (2009). Comparison of measured and simulated water storage in dryland terraces of the Loess Plateau, China. Agric. Water Manag., 96(2), 299-306. DOI: 10.1016/j.agwat.2008.08.010.

Ma, D.H. \& Shao M.A. (2008). Simulating infiltration in stony soil with a dual-porosity model. Eur. J. Soil Sci., 59, 950-959. DOI: 10.1111/j.1365-2389.2008.01055.x.

Ma, D.H., Shao, M.A., Zhang, J.B. \& Wang Q.J. (2010). Validation of an analytical method for determining soil hydraulic properties of stony soils using experimental data. Geoderma, 159(3-4), 262-269. DOI: 10.1016/j.geoderma.2010.08.001.

Marhold, K. \& Hindák F. (Eds.) (1998). Chcecklist of non-vascular and vascular plants of Slovakia. Bratislava: Veda, vydavatel'stvo SAV .

Michalko, J., Berta, J. \& Magic D. (1986). Geobotanická mapa ČSSR, čast’ SSR. Bratislava: Veda, vydavatel’stvo SAV.

Novák, V., Kňava, K. \& Šimůnek J. (2011). Determining the influence of stones on hydraulic conductivity of saturated soils using numerical method. Geoderma, 161(3-4), 177-181. DOI: 10.1016/j.geoderma.2010.12.016.

Nyssen, J., Clymans, W., Poesen, J., Vandecasteele, I., De Baets, S., Haregeweyn, N., Naudts, J., Hadera, A., Moeyersons, J., Haile, M. \& Deckers J. (2009). How soil conservation affects the catchment sediment budget - a comprehensive study in the north Ethiopian highlands. Earth Surface Processes and Landforms, 34(9), 1216-1233. DOI: $10.1002 /$ esp.1805.

Oksanen, J., Guillaume Blanchet, F., Friendly, M., Kindt, R., Legendre, P., McGlinn, D., Minchin, P.R., O'Hara, R.B., Simpson, G.L., Solymos, P., Stevens, M.H.H., Szoecs, E. \& Wagner H. (2019). Vegan: Community ecology package. R package version 2.5-6.

Posthumus, H. \& Stroosnijder L. (2010). To terrace or not: the short-term impact of bench terraces on soil properties and crop response in the Peruvian Andes. Environment, Development and Sustainability, 12(2), 263-276. DOI: 10.1007/s10668-009-9193-4.

Ružičková, H., Dobrovodská, M. \& Valachovič M. (1999). Landscape-ecological evaluation of vegetation in relation to the forms of anthropogenic relief in the cadastre of the Liptovská Teplička Village, the Nízke Tatry Mts. Ekológia (Bratislava), 18(4), 381-400.

Schönbrodt-Stitt, S., Bosch, A., Behrens, T. Hartmann, H., Shi, X. \& Scholten T. (2013). Approximation and spatial regionalization of rainfall erosivity based on sparse data in a mountainous catchment of the Yangtze River in Central China. Environ. Sci. Pollut. Res., 20(10), 6917-6933. DOI: 10.1007/s11356-012-1441-8.

Sun, F., Lü, Y., Fu, B., Ma, Z. \& Yao X. (2013). Spatial explicit soil moisture analysis: pattern and its stability at small catchment scale in the loess hilly region of China. Hydrological Processes, 28, 4091-4109. DOI: 10.1002/ hyp. 9940.

Špulerová, J., Dobrovodská, M., Lieskovský, J., Bača, A., Halabuk, A., Kohút, F., Mojses, M., Kenderessy, P., Piscová, V., Barančok, P., Gerhátová, K., Krajčí, J. \& Boltižiar M. (2011a). Inventory and classification of historical structures of agricultural landscape in Slovakia. Ekológia (Bratislava), 30(1), 157-170. DOI: 10.4149/ekol_2011_02_157. 
Špulerová, J., Dobrovodská, M., Bezák, P., Barančok, P., Boltižiar, M., David, S., Dramstad, W., Ďugová, O., Fjellstad, W., Gajdoš, P., Halada, L., Hreško, J., Izakovičová, Z., Kanka, R., Kenderessy, P., Kollár, J., Krajčí, J., Krištín, A., Krnáčová, Z., Majzlan, O., Moyzeová, M., Petrovič, F., Ružičková, H., Stašiov, S., Šolomeková, T., Šteffek, J. \& Vagačová M. (2011b). Stratégia ochrany a manažmentu historických štruktúr polnohospodárskej krajiny v modelovom území Liptovská Teplička. Bratislava: ÚKE SAV.

Štibinger, J. (2011). Infiltrační schopnosti agrárních valů. Stavební Obzor, 2, 6.

Tichý, L. (2002). JUICE, software for vegetation classification. J. Veg. Sci., 13, 451-453. DOI: 10.1111/j.1654-1103.2002. tb02069.x.

Vachaud, G., Silans, A.P.D., Balabanis, P. \& Vaucli M. (1985). Temporal stability of spatially measured soil water probability density function. Soil Sci. Soc. Am. J., 49, 822-828. DOI: 10.2136/sssaj1985.03615995004900040006x.

Van Wesemael, B., Poesen, J., Sole' Benet, L., Cara Barrionuevo, L. \& Puigdefábregas J. (1998). Collection and storage of runoff from hillslopes in a semi-arid environment: geomorphic and hydrologic aspects of the aljibe system in Almeria Province, Spain. J. Arid Environ., 40, 1-14. DOI: 10.1006/jare.1998.0429.

Verbist, K.M.J., Cornelis, W.M., Torfs, S. \& Gabriels D. (2013). Comparing methods to determine hydraulic conductivities on stony soils. Soil Science Society of America Journal Abstract - Soil Physics, 77(1), 25-42. DOI: 10.2136/ sssaj2012.0025.

Xu, G., Zhang, T., Li, Z., Li, P., Cheng, Y. \& Cheng S. (2017). Temporal and spatial characteristics of soil water content in diverse soil layers on land terraces of the Loess Plateau, China. Catena, 158, 20-29. DOI: 10.1016/j. catena.2017.06.015.

Yang, L., Wei, W., Chen, L.D., Jia, F.Y. \& Mo B.R. (2012). Spatial variations of shallow and deep soil moisture in the semiarid Loess Plateau, China. Hydrology and Earth System Sciences, 16, 3199-3217. DOI: 10.5194/hess-163199-2012.

Zhang, J.H., Wang, Y. \& Zhang Z.H. (2014). Effect of terrace forms on water and tillage erosion on a hilly landscape in the Yangtze River Basin, China. Geomorphology, 216, 114-124. DOI: 10.1016/j.geomorph.2014.03.030.

Zhao, Y., Peth, S.,Wang, X.Y., Lin, H. \& Horn R. (2010). Controls of surface soil moisture spatial patterns and their temporal stability in a semi-arid steppe. Hydrologival Processes, 24, 2507-2519. DOI: 10.1002/hyp.7665.

Zhou, B., Shao, M. \& Shao H. (2009). Effects of rock fragments on water movement and solute transport in a loess plateau soil. Comptes Rendus Geoscience, 341(6), 462-472. DOI: 10.1016/j.crte.2009.03.009. 